\title{
Urethane 誘導体の薬理学的研究
}

\author{
南 \\ 公 \\ 俊

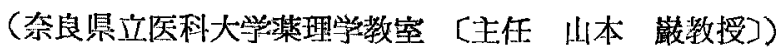 \\ (喵和33年 7 月19日受付[特])
}

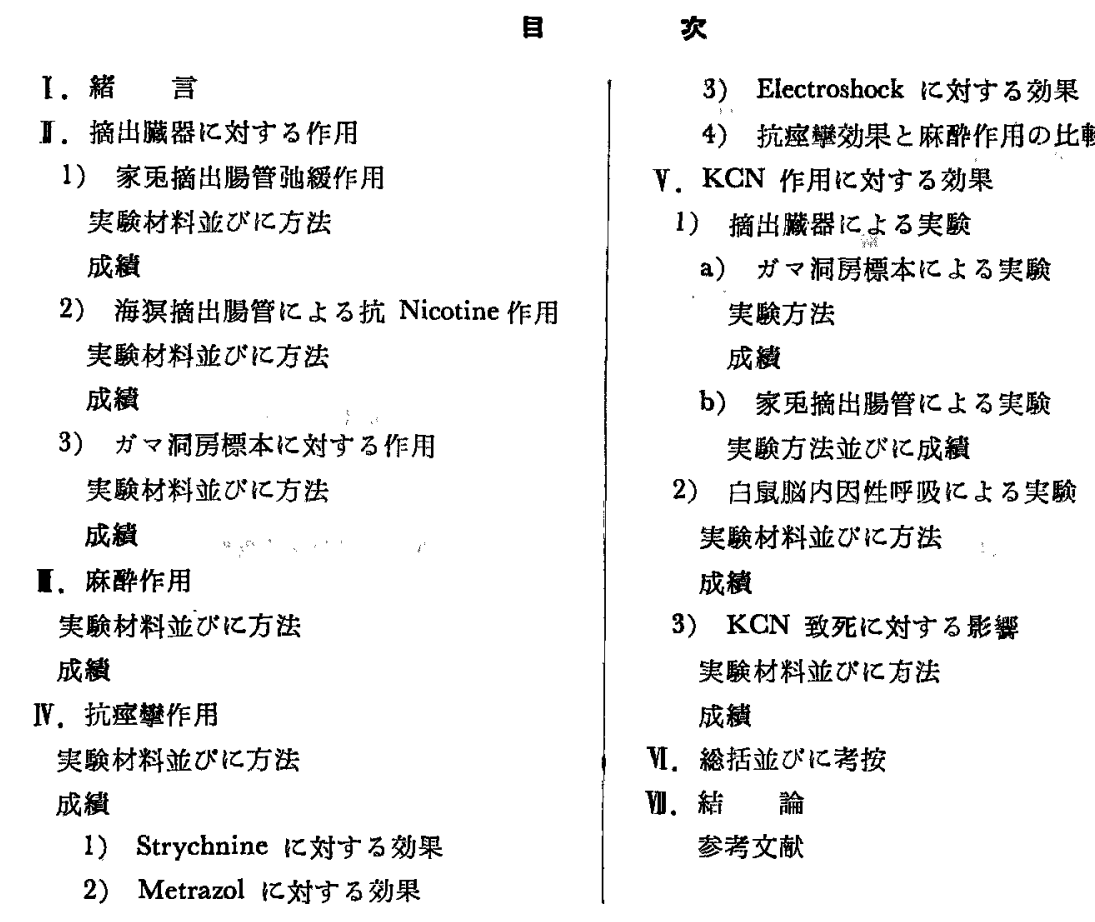

\section{I. 粕}

\section{言}

Ethyl urethane (Et-U) は中权神経抑唰作用以外に Antimitotic action を有することがWarburg)のウニ の卵を用いた実駼によつて指搱され，更に Haddow たち2) が奏験的移植㴼に 対し抑制効果のあること，Pater-

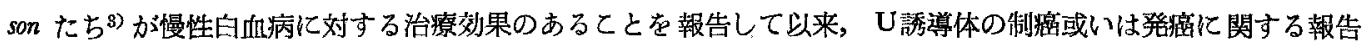
4〜12)は少なくない.

著者はさきに山本，岩田たち 13〜19) と共に Nitrogen mustards について研究を行つて来たが，同じく制瘦物 留の一つとしてもU誘導体に関心を答せていた。

一方，本学生理学教室の鎌倉 ${ }^{20)}$ は日鼠を用い高度低圧に基く酸素欠乏に対して Et-U が特異的に延命效果を 示すととを認め，その共同研究者 ${ }^{21}$ 29) と共に Et-U の生理学的意義について報告を重悋ている. また本学整肜

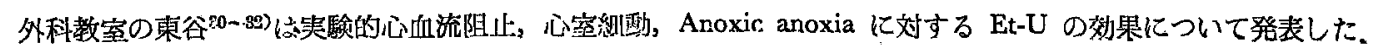


一方，Warburg ${ }^{23)}$ は鵟鳥の赤血球を用いて Methyl (Me), Isobutyl などのU桥導体が KCN の呼四阻害を減少せ しめるととを報じている。

上远のように，U誘導体は実験楽理学上興味ある作用を併せ有しているが，その基本とあなるべき Normal

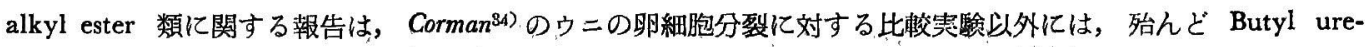
thane (Bt-U) までの誘導体に限られていたので，著者はより高級のU誘導体をも用いて䔧理学的実験を行つた。

なお，本研究に使用したU誘導体（Meより Decyl までのカルバミン酸エステル）は武田研究所において合 成されたものである。

\section{II，摘出荧器に対する作用}

Clark ${ }^{35)}$ は Aliphatic narcotics が蛙摘出心㖪抑制を示すととを報じており，Alcohol ではそのC数の増加に 從い作用の増大するととを指摘している，著者はU誘導体について作用強度を比較するに当り，まず摘出蔵器に 対する作用を目標とし，ての際ガマ摘出心房以外に特に哺乳動物の材料として家鬼及び海猽の腸管を用いるとと とした. Bernheim ${ }^{36)}$ が Histamine, Acetylcholine (ACh)，Pilocarpine の腸管収縮作用に対して Et-U が抑例す ることを報告している。そこで著者は特に Nicotine に対する拈抗作用を取りあげ，その検討も行つた.

\section{1）家鬼摘出腸管弛悢作用}

\section{実験村料亚びに方法}

体重 $3 \mathrm{~kg}$ 前後の家鬼の小腸を摘出し，Magnus 法に従つて腸管の運動に対する影響を煤紙上に記録した。 乙

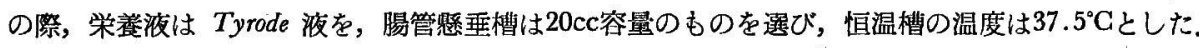

\section{成䋨}

U誘導体は，いずれ屯家鬼摘出腸管の振巾を減小すると共に緊張を低下せしめた．その一例として，Oc-U

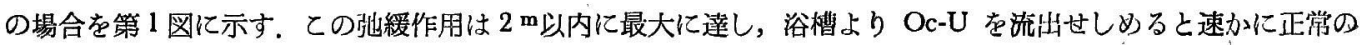
緊張に恢復するととが認められた。

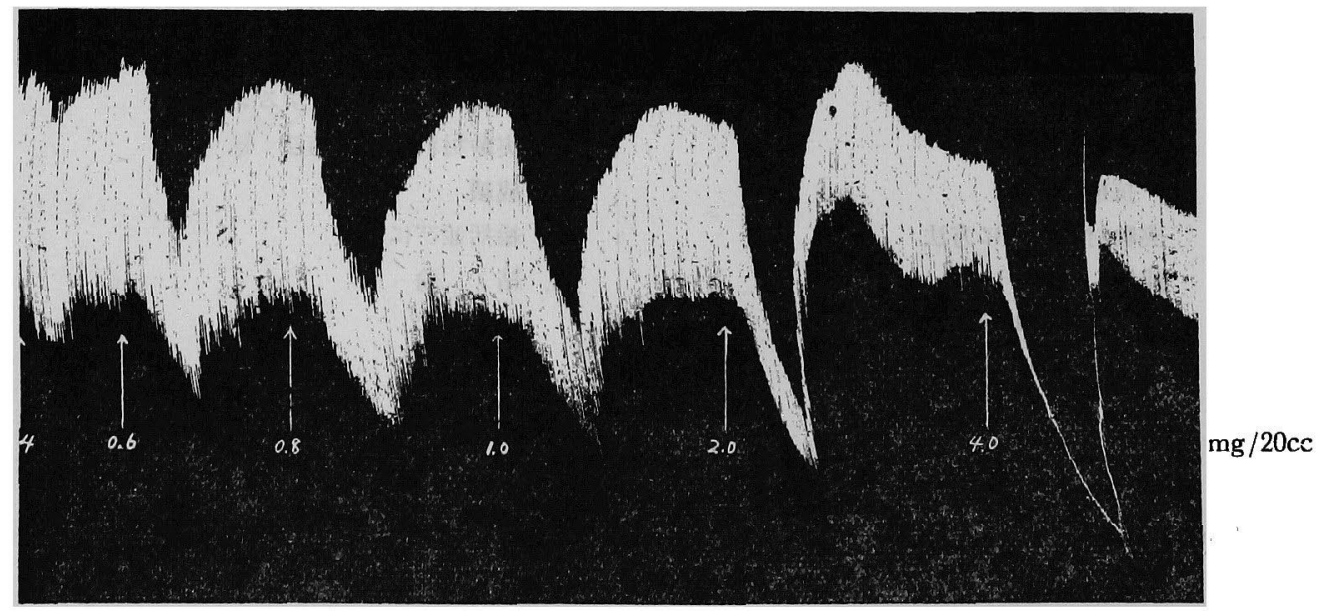

第 1 図．家鬼摘出腸管に対する Octyl urethane の作用.

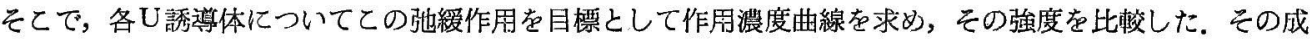

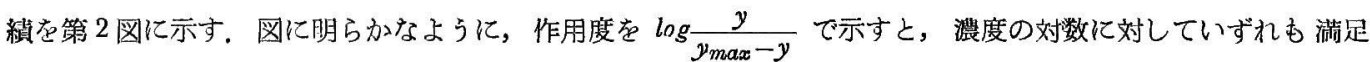
すべき值線関係が得られ，しかも高級になるに従つて左に移動するととから，作用強度が略々 Alkyl のC数に 比例して堌大することが羿められた，伹し，Nonyl U 以上では却つて娍弱して来る。

2.)海经摘出腸管による抗 Nicotine 作用 


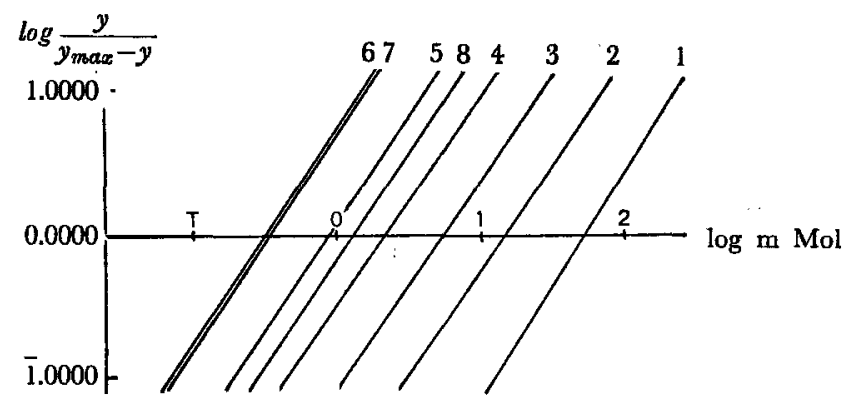

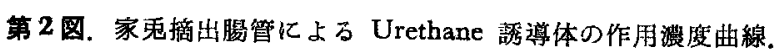

(1): Ethyl U (3): Butyl U (5): Hexyl U (7): Octyl U

(2): Propyl U (4): Amyl U (6): Heptyl U (8) : Nonyl U

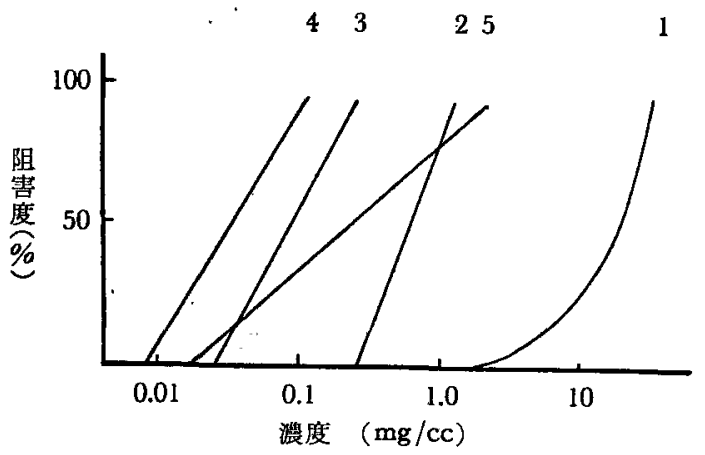

第 3 图. Urethane 誘導体の Nicotine に対守る

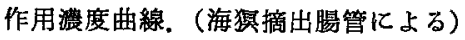

(1): Ethyl U (3): Hexyl U (5) : Nonyl U

(2) : Butyl U (4) : Octyl U

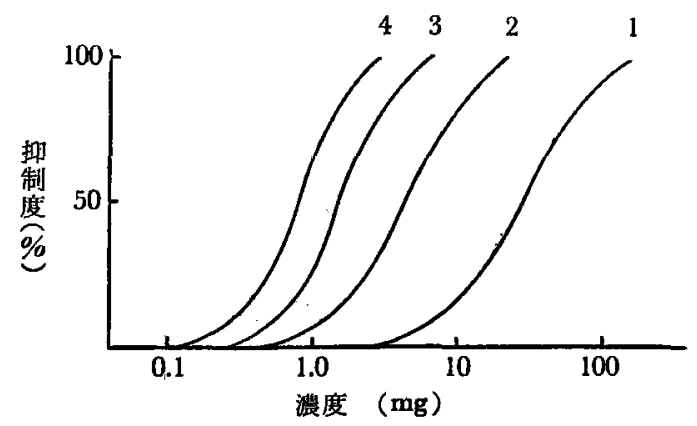

第4图、ガマ洞房標本によるUrethane 係導体の 作用濃度曲楾。
(1) : Ethyl U
(3) : Butyl U
(2) : Propyl U
(4) : Amyl U た.

\section{実検材料並ひた方法}

体重400g前後の海㩧を用い，前項 と同一条件にて Magnus 法を施行した。

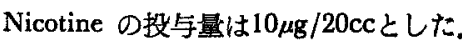

\section{成转}

海猽摘出小腸を用い， Nicotine， $\mathrm{ACh}$ なとの収縮薬に対し，U諉導体 が拮抗作用を示すことを認めたので， この拮抗度の此较を行つた. Nicotine に対する抑制度を管 3 図に示す。図に みられるように，抗 Nicotine 作用も Oc-U まで高級になるに従つて增大す るととが諗められた。

3）ガマ洞昘標本に対する作用

\section{夷䮦材料並びに方法}

体重 $150 \mathrm{~g}$ 前捘の雄性ガマを用い，山風 ${ }^{37)} の$ 記载に従つて実施した。

\section{成綪}

ガマ洞房徱本と対し，U誘導体はその振巾 を減小せしめることを認めたので，その作用濃 度曲線を求めた，その成䋶を第 4 図に示す。乙

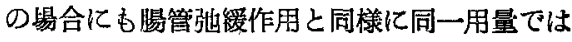
渞級になるに従つて作用が增大するととが認め られた。

\section{III：麻 酔 作 用}

次に，U誘導体の主作用である中枢神経抑 俳作用 ${ }^{38)}$ を目標として，作用强度の比較を行つ

\section{荑喝材料並びに方法}

体重 $15 \mathrm{~g}$ 前後の健常dd系マウスを使用し， 検体は水溶液とし，難溶の多のは Tragacanth 末を $0.5 \%$ 割に加え懸濁液として，腹腔内に 注射した，注射量は0.1cc/10gとした。

投与により発現する症状を，次の各段階に 分類した。

$$
\begin{aligned}
& \text { 一：影蝆の諗むられなかつたもの } \\
& \text { 士 : 自意運動消失のみが諰められた }
\end{aligned}
$$

十 自意運動が消失し，この際，刺钱により体を動かすがをの連動緶慢なるの

$H:$ 運動麻瘦の後，腹位乃至横位をとり刺㦸に対して反応を示さな女子の

成椟

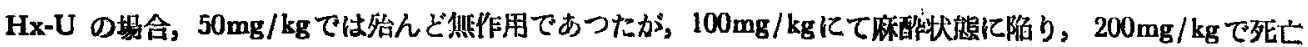




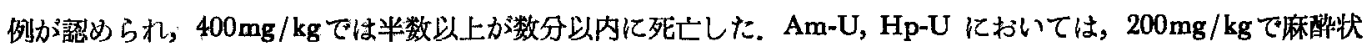
態がみられるが死亡例は $400 \mathrm{mg} / \mathrm{kg}$ 以上にて出現した，その他の成績は一括して第 4 表に示す．以上より，磨醉 作用は Hx-U が最む少量で発現するととが認められ，又毒性す $\mathrm{Hx}$-U が最大を示すととが筧われた。

\section{IV. 抗痤作用}

特に麻醅量以下に重点をおいて，U誘導体の前投与による各種の痙戀に対する影響を比校した。

\section{英塗材料並びに方法}

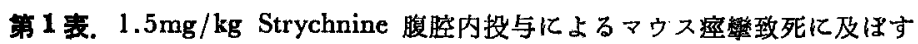
Urethane 誘導体（腹腔内 $30^{\mathrm{m}}$ 前投与）の影響。

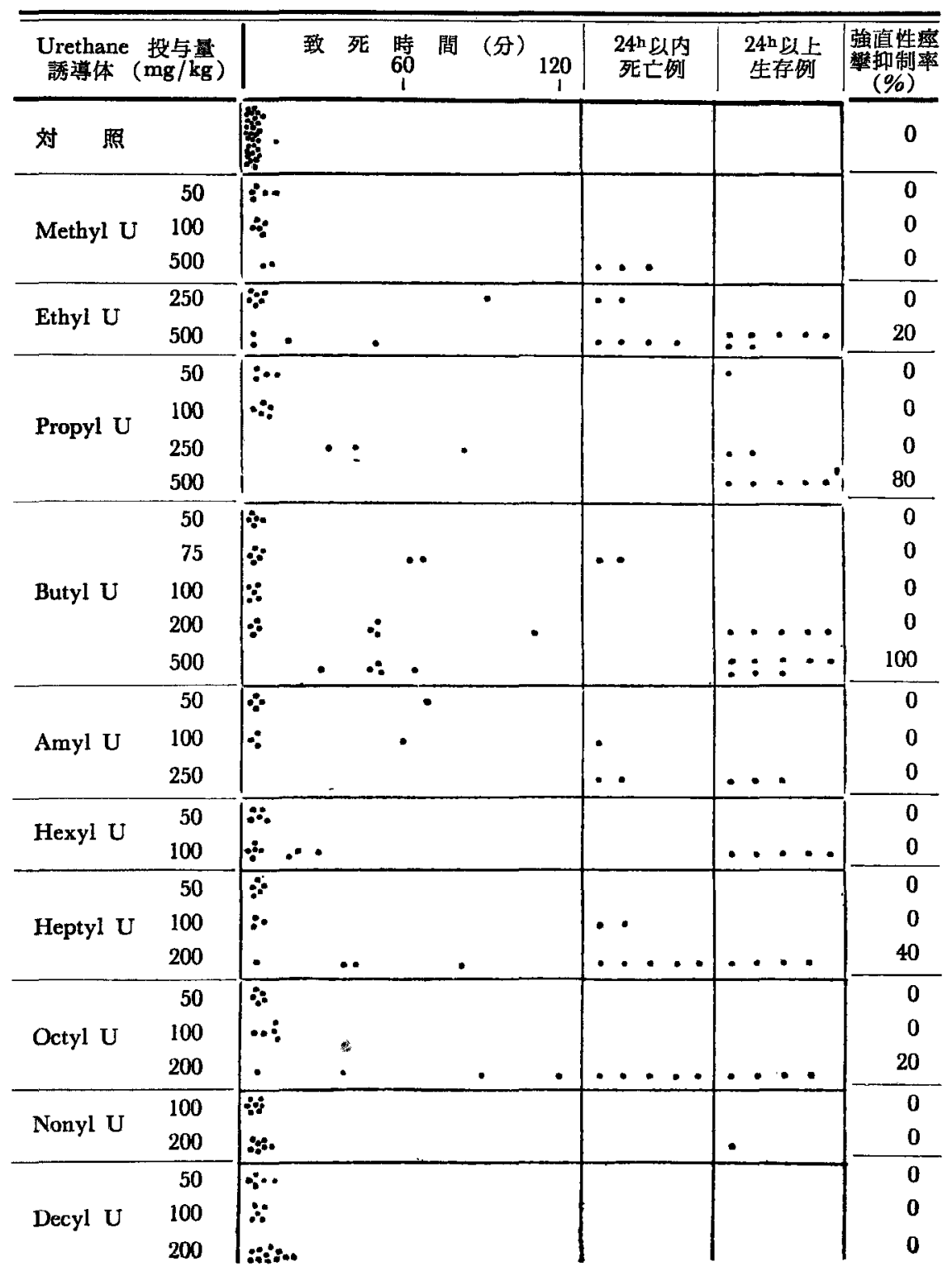




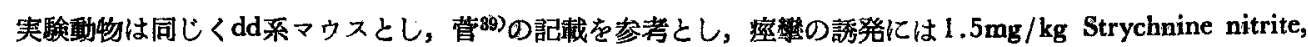
$120 \mathrm{mg} / \mathrm{kg}$ Metrazol の腹腔内注射及び Electroshock を用いた. Electroshock は Toman たち40の記载に准じ， Electric stimulator を使用し，角膜電極を介して $80 \mathrm{~mA} ， 0.2^{\mathrm{s}}$ 間通電することによつた。抗氫繁効果はU誘䢘体

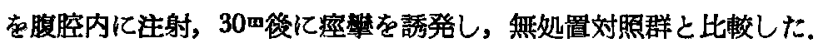

\section{咸嵀}

\section{1) Strychnine に対する効果}

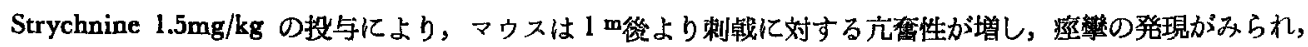

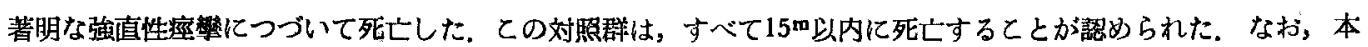
量は Strychnine の LDs8-a に相当した。

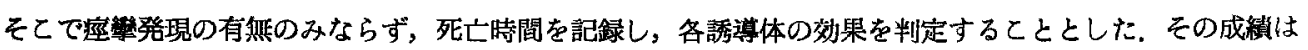

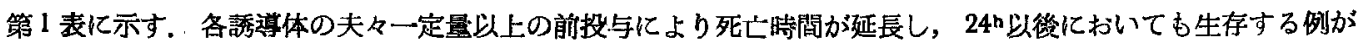

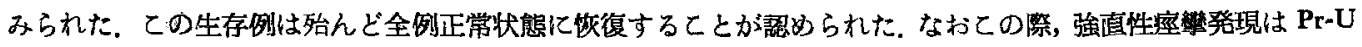
及び Bt-U の麻醉量前投与群で抑制される例がみられたが，その他では痦等発作を抑制する効果はいずれも不碓 実であつた.

2) Metrazol に対する効果

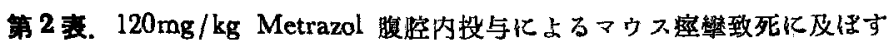
Urethane 誘導体（腹腔内30m前投与）の影䍌。

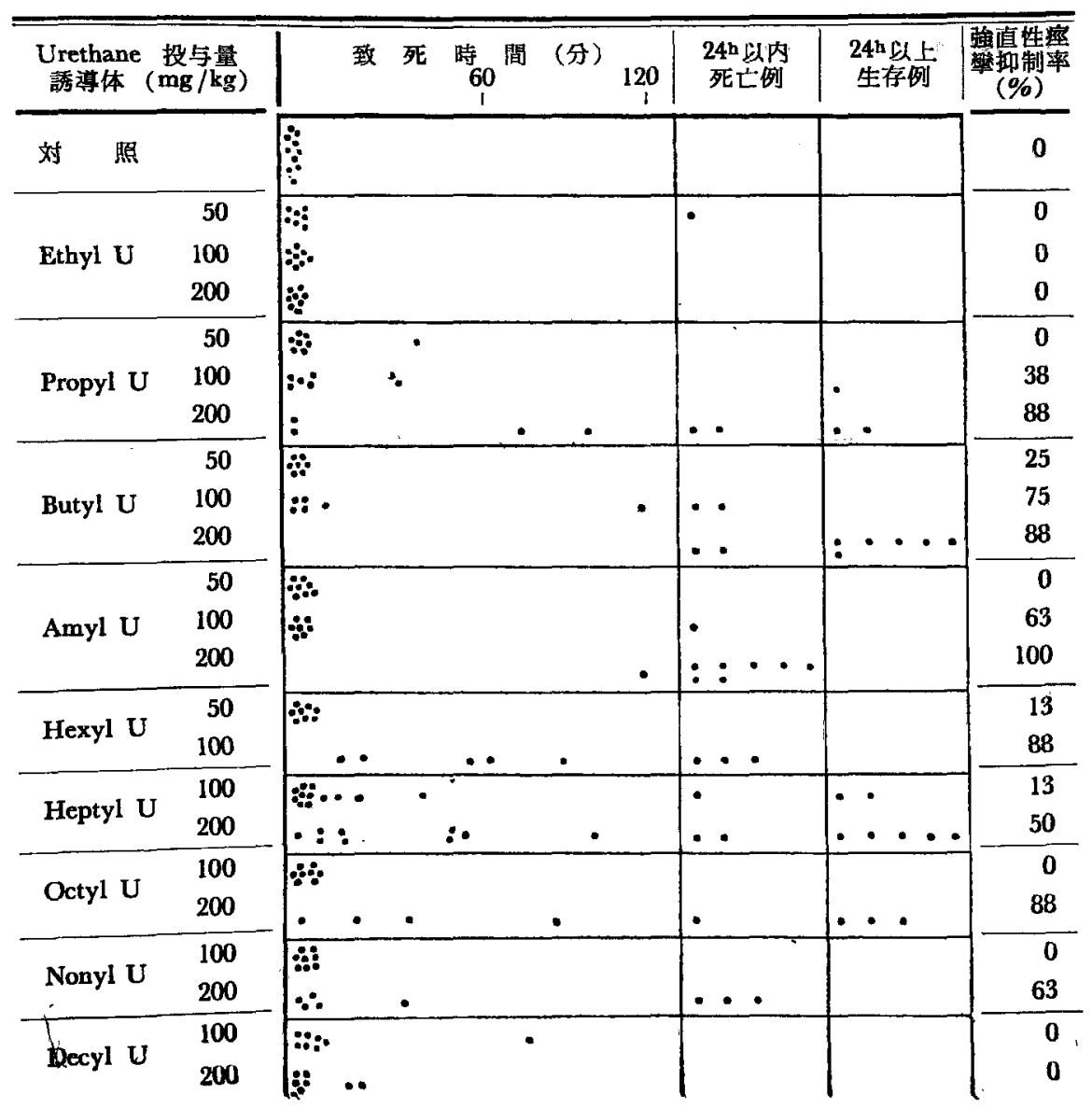


Metrazol $120 \mathrm{mg} / \mathrm{kg}$ の投与により，直ちに與奮状

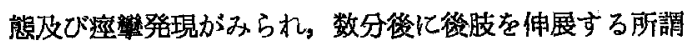
tonic extensor seizure の発現につづいて死亡した. この 死亡は10五以内に観察された。 なお，本量は Metrazol の LD 0 9.8 亿相当した。 各誘導体の効果は第 2 表に示す。 Strychnine の場合と同樣に死亡持間の延長及び24h 以筷 の生存例が認められたが，强直性瘭䀘の抑制率は前者よ りあ大きかつた。

\section{3) Electroshock に対する効果}

刘照群は， $80 \mathrm{~mA} ， 0.2^{\mathrm{g}}$ の通電化上り全例 tonic extensor seizure の発現が認められた。 てれに対する各 誘導体の效果は第 3 表に示す。

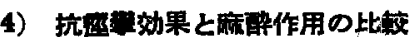

以上の各誘導体の抗空㘘効果を，その麻醉作用と対 比して一括第 4 表に示す．乙の場合，抗空警勃果につい ては Strychnine 及び Metrazol では致死防止率を， Electroshock では Antiextensor の率を示した。

\section{V，KGN 作用に対与る効果}

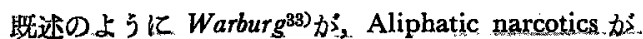
KCN 呼四阻搳を诚少するてとを報して以来，その拮抗

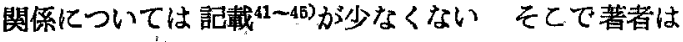

第 3 表。 Urethane 誘導体 $\odot$ Electroshock $\left(80 \mathrm{~mA}, 0.2^{\mathrm{s}}\right)$ 飞対する效果。

\begin{tabular}{|c|c|c|c|c|}
\hline $\begin{array}{c}\text { Urethane } \\
\text { 誘道体 }\end{array}$ & $\begin{array}{c}\text { ( } \mathrm{mg} / \mathrm{kg}) \\
\end{array}$ & $\begin{array}{l}\text { 奏娩 } \\
\text { 列数 }\end{array}$ & $\begin{array}{l}\text { 強㨁性伸 } \\
\text { 展防止数 }\end{array}$ & 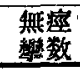 \\
\hline \multirow{3}{*}{ Ethyl U } & 100 & 10 & 3 & 0 \\
\hline & 200 & 10 & 3 & 0 \\
\hline & 400 & 10 & 8 & 1 \\
\hline \multirow{3}{*}{ Propyl U } & 100 & 10 & 3 & 1 \\
\hline & 200 & 10 & 10 & 0 \\
\hline & 400 & 10 & 10 & 2 \\
\hline \multirow{3}{*}{ Butyl U } & 100 & 10 & 9 & 1 \\
\hline & 200 & 10 & 10 & 0 \\
\hline & 400 & 10 & 10 & 6 \\
\hline \multirow{3}{*}{ Amyl U } & 50 & 10 & 0 & 0 \\
\hline & 100 & 10 & 0 & $\theta$ \\
\hline & 200 & 10 & 2 & 0 \\
\hline \multirow{2}{*}{ Hexyl U } & 50 & 10 & 0 & 0 \\
\hline & 100 & 18 & 7 & 5 \\
\hline \multirow{2}{*}{ Heptyl U } & 100 & 8 & 2 & 1 \\
\hline & 200 & --8 & 7 & 5 \\
\hline \multirow{2}{*}{ Octyl U } & 100 & 8 & 4 & 1 \\
\hline & 200 & 8 & 7 & 2 \\
\hline \multirow{2}{*}{ Nonyl U } & 100 & 8 & 2. & 0 \\
\hline & 200 & 8 & 7 & 1 \\
\hline Decyl U & 200 & 8 & 1 & 1 \\
\hline
\end{tabular}

第 4 表. Urethane 諉導体の麻醉作用と抗室攀効果，

\begin{tabular}{|c|c|c|c|c|c|c|c|c|c|c|c|c|c|c|c|}
\hline \multirow{2}{*}{$\begin{array}{c}\text { Urethane } \\
\text { 誘導体 } \\
\\
\text { 投与量 }(\mathrm{mg} / \mathrm{kg}) \\
\end{array}$} & \multicolumn{4}{|c|}{ 麻酳作 用* } & \multicolumn{4}{|c|}{$\begin{array}{l}\text { Strychnine } \\
\text { 致死防柾留 } \\
(\%)\end{array}$} & \multicolumn{3}{|c|}{$\begin{array}{l}\text { Metrazol } \\
\text { 致死防止率" } \\
\text { "(\%) }\end{array}$} & \multicolumn{4}{|c|}{ 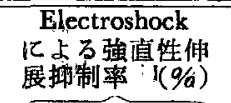 } \\
\hline & 50 & 100 & 200 & 400 & 50 & 100 & 200 & 400 & 50 & 100 & 200 & 50 & 100 & 200 & 400 \\
\hline Methyl U & & & & - & 0 & 0 & & $\mathbf{0}$ & & & $\because$ & & & & \\
\hline Ethyl U & & & & - & & & 0 & 47 & 0 & 0 & 0 & & 30 & 30 & 80 \\
\hline Propyl U & & : & - & + & 20 & 0 & 40 & 100 & 0 & 13 & 25 & & 30 & 100 & 100 \\
\hline Butyl U & & - & + & D & 0 & 0 & 38 & 62 & 0 & 0 & 75: & & 70 & 100 & 100 \\
\hline Amyl U & - & + & $H$ & D. & 0 & 0 & 60 & & 0 & 0 & 0 & 0 & 10 & $20 !$ & \\
\hline Hexyl U & - & H & D & & 0 & 38 & & & 0 & 0 & & 0 & 39 & & \\
\hline Heptyl U & - & \pm & $H$ & D & 0 & 0 & 31 & & & 11 & 31 & & 25 & 88 & \\
\hline Octyl U & & - & + & D & 0 & 0 & 31 & & & 0 & 38 & & 50 & $88^{5}$ & \\
\hline Nonyl U & & - & \pm & & & 0 & 13 & & & 0 & 0 & & 25 & 88 & \\
\hline Decyl U & & - & \pm & & 0 & 0 & 0 & & & ö & & & & 13 & \\
\hline
\end{tabular}

表中十の段階は本交参照，Dは死亡例の認めたものを示す!弰!

上記U誘導体によつて得た知見を基として，ガマ洞房僄本，家白摘出腸管のみならず，哺乳動物の呼吸系として 白鼠脳を選び，乙れらに対する KCN 作用に及ぼすU誘導体の影響を観察し，“莄に KGN 致死に対する効果を あ併せ検討した。

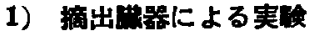

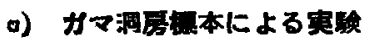




\section{実験方法}

前述の方法に従い,ガマ洞居標本に対するKCN の作用を観察し，U誘導体の影響は，あらかじめ灌 流液に一定の濃度の割合に各誘導体を混和したもの を対照液と切り換えて比較した。

\section{成精}

KCN はガマ洞房標本の振门を減小せしめるが， 再び正常の振门に恢復することが認められた。 そと でその作用㳑度田線を求めた後, U莠導体添加灌流 液中で同樣に作用濃度曲線を湘定した，U誘導体の 添加量は振巾に対し殆んど惩影響のむのを選んだ。 その中, $100 \mathrm{mg} \% \mathrm{Et}-\mathrm{U}, 50 \mathrm{mg} \% \mathrm{Pr}-\mathrm{U}, \quad 2.5 \mathrm{mg} \%$ $\mathrm{Bt}-\mathrm{U}$ 及び $0.05 \mathrm{mg} \%$ Oc-U の成績を篛 5 図に示す. 図に見られるように，いずれも刘照に比し大きい変 動を示さなかつた，それ以下の瀑度及びをの他のU 誘導体についても同梂の結果に終つた.

\section{b）家鬼摘出腸管による実験}

\section{実験方法並びに成綪}

$\mathrm{KCN}$ は腸管弛楥作用を示し，浴槽より $\mathrm{KCN}$ を流出せしめると再びもとの㹂張にまで恢復するこ とが認められた，栄趁液にU誘導体を添加したむの

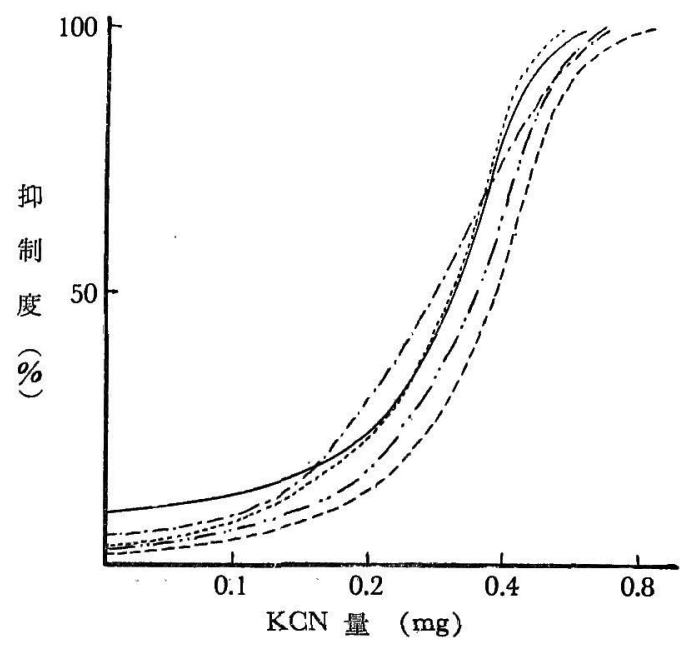

第 5 図。ガマ洞房標本に打ける KCN の作用濃度 曲線に及ほすす Urethane 誘導体の影㗽。

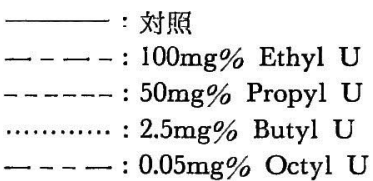

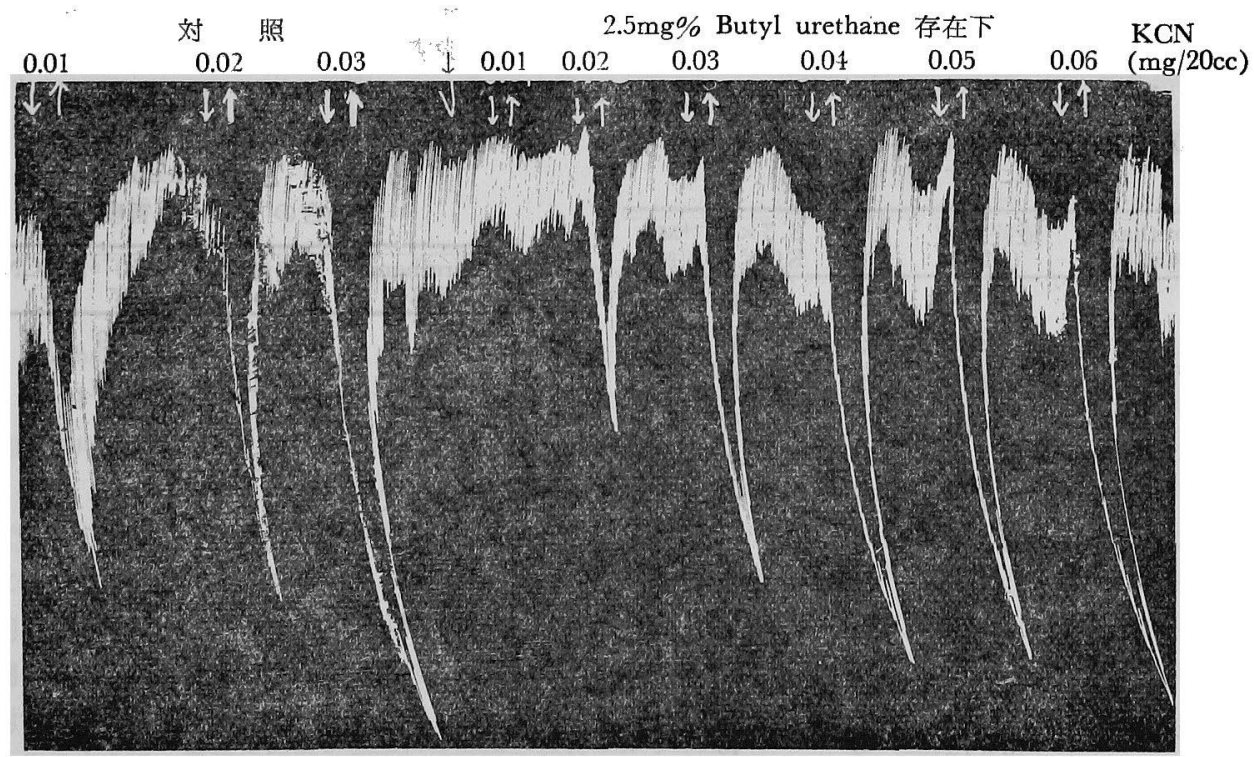

第 6 図. KGN の家灰摘出渴管弛綬作用に及ぼす Butyl urethane の影響.

と置換すると KCN の弛緩作用が減弱されるととが認められる。一例として $2.5 \mathrm{mg} \% \mathrm{Bt}-\mathrm{U}$ の場合を筙 6 図に示 す.

そこで，KGN の弛緩作用を目標として，作用潂度曲線を求め，それ自体腸管の繁張に影響を及ぼさないU 誘導体存在時のそれと比銢した所，第７図に示す如くいずれむ KCN と拮抗することが認められた。 
1064

南

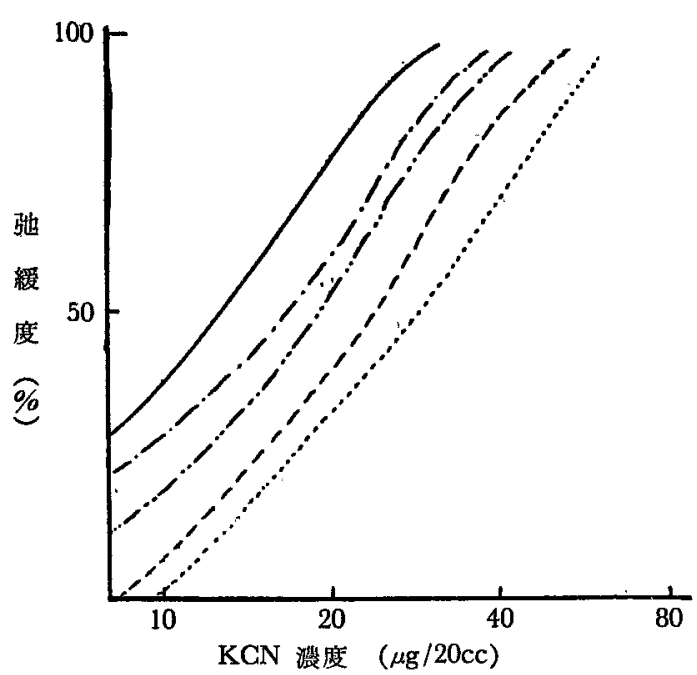

第 7 图. 家鬼摘出馏管に打ける $\mathrm{KCN}$ の作用濃度曲線 に及はす Urethane 誘導体の影餐。

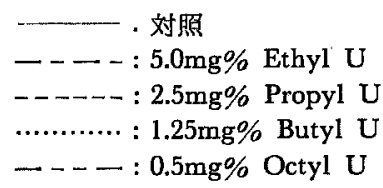

第 5 表. Urethane 誘導体の白毁脳内因性 呼吸汶対方阻害度 (\%)。

\begin{tabular}{|c|c|c|c|}
\hline $\begin{array}{c}\text { Urethane } \\
\text { 語導体 }\end{array}$ & $\begin{array}{c}\text { 焣終浀度 } \\
(\mathrm{Mol}) \\
\end{array}$ & 単独 & $\begin{array}{l}3.3 \times 10^{-4} \mathrm{M} \\
\text { KCN 併用時 }\end{array}$ \\
\hline \multirow{4}{*}{ Ethyl U } & 0 & - & 39 \\
\hline & $2 \times 10^{-1}$ & 23 & 38 \\
\hline & $1 \times 10^{-1}$ & 13 & 48 \\
\hline & $5 \times 10^{-3}$ & 0 & 37 \\
\hline \multirow{5}{*}{ Propyl U } & 0 & 一 & 45 \\
\hline & $5 \times 10^{-2}$ & 24 & 49 \\
\hline & $2.5 \times 10^{-2}$ & 19 & 45 \\
\hline & $1 \times 10^{-2}$ & 14 & 39 \\
\hline & $5 \times 10^{-3}$ & 8 & 48 \\
\hline \multirow{4}{*}{ Butyl U } & 0 & - & 42 \\
\hline & $1 \times 10^{-2}$ & 16 & 36 \\
\hline & $5 \times 10^{-3}$ & 6 & 40 \\
\hline & $1 \times 10^{-3}$ & 0 & 42 \\
\hline \multirow{2}{*}{ Amyl U } & 0 & 一 & 39 \\
\hline & $2 \times 10^{-3}$ & 15 & 39 \\
\hline
\end{tabular}

阻害度は $2^{\mathrm{n}}$ 值を示す。
公

俊

\section{2）白閶腷內因性呼吸による実駼}

\section{実験材料並びに方法}

健常白鼠（体重150 200g）の全脳を断頭後 速汃々摘出し，承冷 Krebs-Ringer 燐酸緩衙液を $100 \mathrm{mg}$ 組織/ccとなるように加光，Potter-Elveh$j e m$ 型 Homogenizer にて，外部を冷却しなが ら homogenize し，モスリン布で濾過したも のを 10\% Homogenate として用いた。

酸素消費は Warburg の装跮を用い，mano metric に測定した。温度は $37.5^{\circ} \mathrm{C}$ ，ガス腔は 空気とした。

\section{成䋖}

U誘導体はそれぞれ一定濃度以上にて，内 因性呼吸の阻害を示した. $3.3 \times 10^{-4} \mathrm{M}$ ～KCN と同時添加して呼吸の影響を見ると，第 5 表 亿示すように殆んどの例が KCN の単独阻害を 若干上廻るか，略々等しいととが認められたが， Bt-U では KCN の阻害度を減少せしぬる㑯向 あ觉われた。

次に，U誘導体と Homogenate 15 m間， preincubate し，KCN を添加した，その阻害 度は第 6 表に示すように対照 KCN のそれより あ減少することが認められた。

第 6 表. Urethane 誘渞体を脳 Homogenate $\&$ Preincubation $U$ た場合の KCN 阻害度.

\begin{tabular}{|c|c|c|}
\hline $\begin{array}{l}\text { Urethane } \\
\text { 誘導体 } \\
\end{array}$ & $\begin{array}{c}\begin{array}{c}\text { 最終澎度 } \\
(\mathrm{Mol})\end{array} \\
\end{array}$ & $\begin{array}{l}3 \times \overline{10^{-4} \mathrm{MKCN}} \\
\text { 阻害度 }(\%)\end{array}$ \\
\hline \multirow{3}{*}{ Ethyl U } & 0 & 39 \\
\hline & $2 \times 10^{-1}$ & 35 \\
\hline & $1 \times 10^{-1}$ & 28 \\
\hline \multirow{3}{*}{ Propyl U } & 0 & 39 \\
\hline & $5 \times 10^{-2}$ & 22 \\
\hline & $5 \times 10^{-3}$ & 31 \\
\hline \multirow{3}{*}{ Butyl U } & 0 & 40 \\
\hline & $1 \times 10^{-2}$ & 28 \\
\hline & $1 \times 10^{-8}$ & 34 \\
\hline
\end{tabular}

阻害度は $2^{\mathbf{b}}$ 值を示す。 


\section{3) KĆN 致死に対する影澪}

\section{実験村料並びに方法}

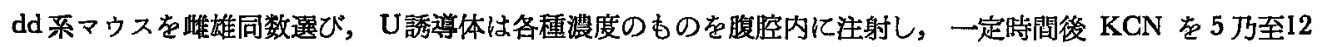
$\mathrm{mg} / \mathrm{kg}$ の 5 水準以上を皮下に注射した．注射量はいずれも0.1 cc/10gとなるようにした．各水準における実験動 物数は10〜20匹である。致死量はプロビっト法によりLD旅算定した。

\section{成楼}

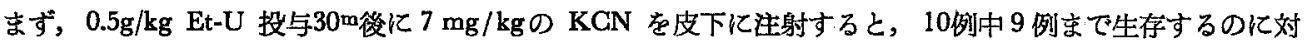
し，対照の KCN 単独では10例中 1 例しか生存しないととが翀められた.

そこで，LD㐫の測定を行い，Et-Uによつて得た成續を第 7 表に示す.

前投与の㭙䦭的関保の検討から 15〜60mの間に大差が見られなかつたので，以後の笑験は全て前投与の時間 を30mとした.

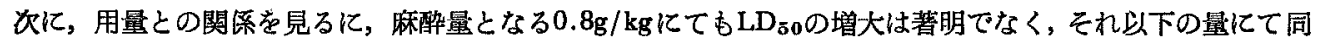
一の成縝を得られたととは與味がある。

それ以外の誘導体によつて得た成績を，一括して第 8 表行示す。

第 7 表. マゥスに扔ける KCN のLD 及ぼす Ethyl urethane の影盟.

\begin{tabular}{ccc}
\hline $\begin{array}{c}\text { Ethyl urethane } \\
\text { 投与量 }(\mathrm{g} / \mathrm{kg})\end{array}$ & $\begin{array}{c}\text { 前投与時間 } \\
(\text { 芀 })\end{array}$ & $\begin{array}{c}\mathrm{KCN} \mathrm{LD} \\
(\mathrm{mg} / \mathrm{kg})\end{array}$ \\
\hline 対照 & & $6.5 \pm 1.0$ \\
0.05 & 30 & $8.6 \pm 1.0$ \\
0.25 & 30 & $9.0 \pm 1.0$ \\
0.5 & 15 & $9.2 \pm 1.1$ \\
& 30 & $9.2 \pm 1.0$ \\
& 60 & $8.7 \pm 1.0$ \\
0.8 & 30 & $9.1 \pm 1.0$
\end{tabular}

第8 表. マウスに捛ける KCN の LD 謡導体の影響.

\begin{tabular}{crr}
\hline $\begin{array}{c}\text { Urethane } \\
\text { 誘導体 }\end{array}$ & $\begin{array}{c}\text { 投与量 } \\
(\mathrm{mg} / \mathbf{k g})\end{array}$ & $\begin{array}{c}\text { KCN LD } \\
(\mathrm{mg} / \mathrm{kg})\end{array}$ \\
\hline 対 照 & & $6.5 \pm 1.0$ \\
Methyl U & 252 & $9.4 \pm 1.0$ \\
Propyl U & 40 & $8.2 \pm 1.0$ \\
& 290 & $9.5 \pm 1.1$ \\
Butyl U & 66 & $10.0 \pm 1.1$ \\
& 131 & $8.8 \pm 1.0$ \\
Amyl U & 74 & $10.0 \pm 10$ \\
Octyl U & 10 & $8.1 \pm 1.0$
\end{tabular}

\section{可. 縊括並びに考按}

Aliphatic narcotics については，その作用が品級になるに従つて增大すると報告听,11)されており，又，Normal alkyl ester のU誘導体については，Corman $\left.{ }^{34}\right)$ が Alkyl 基の C 数が10迄增加するに従つてウニの卯の細胞分 裂抑制作用が増大するととを報告している。

今回，著者はこれらU誘導体の各喠の作用を比軦し，同一效果を招来するに要する用量が，高級になるに従 つて娍じて来るてとから，作用強度が高級になるに従つて增して行くことを認めた．所が，各作用の目標が異な るに従つて最強となる Alkyl 基のC数が移動する，即ち，摘出臟器を目標とした場合，まず家躳摘出腸管弛緩 作用では Oc-U がピークとなり，ついで海狽摘出腸管による抗 Ntcotine 作用, 又がマ洞房標本振门減小作用で あ同一の傾向が認めら机た，乙れ対し，中权作用である麻酔作用では $\mathrm{Hx}-\mathrm{U}$ がピークを示すとと，又，用量 に対するマウスの死亡数から瑇性も同しピークを示すととを認めた。

このように，最強の作用を示すU侤導体が異なるととは注目すべきととと考える。

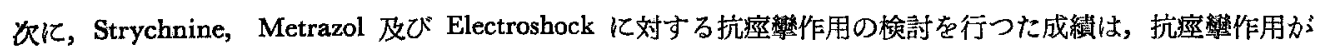
麻醉作用と略々平行する傾向を示したが，Hx-U，Am-U では有効量と致死量とが近接しているため，奻果が確

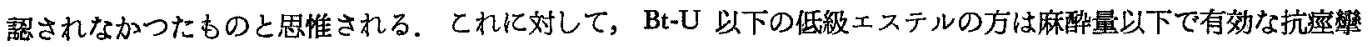
作用が認められたてとは與味ある事実である。

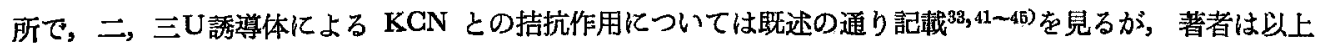


1066

南

公

俊

検討を加えて来たU誘導体の作用を目標とした場合，KCN との拮抗が確認されるか不かについて実験を重ねた。 その結果，ガマ洞房標本沈いて，作用濃度曲線による検討汃らその拮抗作用住有意ではなかつた。しかし乍ら，

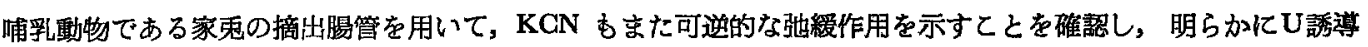
体がこの作用を娍弱せしぬるととを認めた。所で，Warburg ${ }^{38,427}$ は KCN の細胞呼吸阻害をU誘導体が減少せし

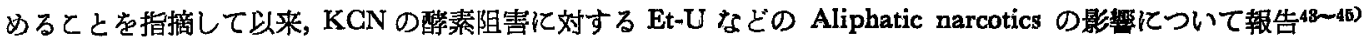
を見る。そてで著者は，同じ現象が哺乳動物によつても諮められるか不かを知る目的で，白鼠媨の呼吸に対する

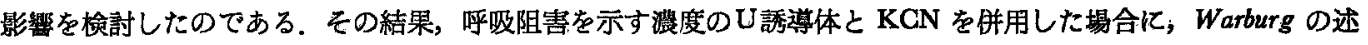
べているように，KCN の阻害度が上笲しないととを認めた，てのてとに関しては，KCN は Cytochrome 系を 阻害するが，Et-Uなどの Aliphatic narcotics はこの系を抑制せず，Dehydrogenase 系を刎制するものであるて

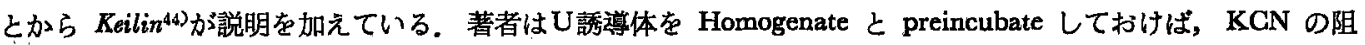
害が減少する成績を得たので甚だ興味深く思つている。

更に，著者は KCN の致死眰が Am-U までの誘導体の前投与によつて增加し，ての際，Et-Uをはじめと して麻䤃量においても，その増大度が大きくならず,むしろ subnarcotic dose そおいて効果を認めたてとは注目 すべき事実である.

\section{VII. 結 論}

Urethane 誘導体，即ち，Methyl から Decyl までのカルバミン酸エステルについて蒋理学的性筫の柃討を 行つた.

1. 摘出腸管に対する驰緩作用は高級になるに従つて堌大するが, Octyl uretbane が最強であつた.

2. 麻醉作用は Hexyl urethane が最强であつた，Butyl 以下の Urethane 誘導体の抗座彎作用は麻醉量以 下で認められた。

3. 家躳摘出晹管，白鼠脳の内因性呼吸及びマウスの致死に対する KGN の作用を，Amyl urethane 以下の 誘導体が減弱せしめるととを認めた。

本論文要旨は，第12回日本㔨理学会近譏部会，第31回日本薬理学会絵会に於て発表した。

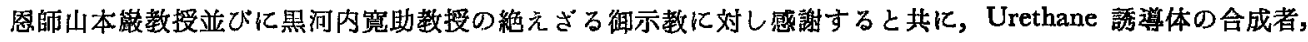
武田研究所西光缚氏に深譤する。

\section{参 考 交 塥}

1) Warburg, O. . Hoppe-Seyl. Z. 66, 305 (1910).

2) Haddore, A. \& Sexton, W.A. : Nature 157, 500 (1946).

3) Paterson, E., Haddow, A., Tomas, I. \& Watkinson, J.M. : Lanceț 250, 677 (1946).

4) Nettleship, A., Henshaw, P.S. \& Meyer, H.C. : J. Ntl. Cancer Inst. 4, 309 (1943).

5) Dustin, $P$. : Nature 159, 794 (1947).

6) Murphy, J.B. \& Sturn, E. : Cancer Res. 7, 417 (1947).

7) Dustin, P. : Brit. J. Cancer 1, 48 (1947).

8) Lushbaugh, C.C., Green, J.W. \& Storer, J.B. : J. Ntl. Cancer Inst. 8, 201 (1948).

9) Noble, R.L. \& Millar, M.J.: Nature 162, 253 (1948).

10) Skipper, H.E., Bryan, C.E., Riser, W.H., Welty, M. \& Stelzenmuller, A. : J. Ntl. Cancer Inst. 9, 77 (1948).

11) Skipper, H.E. : Cancer 2, 475 (1947).

12) Florijn, E. \& Smits, G. : Nature 164, 699 (1949).

13) 山本管: 奈医誌 5, 93 (1954).

14）山本馓，岩田平太郎，山岡正幸：周誌 4，3号，16 (1953). 
15) 岩田平太郎，南公俊，吉本恵則，板野竜光：同誌 5，60 (1954).

16) 岩田平太郎, 北村武久, 山岡正幸：日薬理誌 50, 169 (1954).

17）山本臀，岩田平太郎，北村武久，山田正興，生駒栄喜，加藤光二：奈医誌 5, 55 (1954).

18) Iwala, H., Yamaoka, M., Minami, M. \& Yamamoto, I. : Jap. J. Pharmacol. 4, 168 (1955).

19）岩田平太郎：日䒚理誌 52, 73 (1956).

20）鉳倉勝夫，海城済，中馬一郎：日生理誌 13，24（1951）.

21）海城济 : 奈医誌 3，3号，12 (1952).

22）銀倉腾夫，中馬一郎，嵦越美夫 : 生体の科学 5, 80 (1953).

23）嶋越美夫：日生理誌 15，622 (1953).

24）鏮倉腾夫，鳰越美夫，森川昍：同誌 16，234（1954）.

25) Kamakura, K., Morikawa, A. \& Kaijo, W. : Jap. J. Physiol. 5, 16 (1955).

26）中馬一郎, 森川昭 : 奈医婄 6, 23 (1955).

27) 中馬一郎，辻井主，鵜山浩之斿，原芳子：同誌 6, 67 (1955).

28）鏮倉勝夫，沜越美夫，森川昭，樢山浩之裙：同誌 5, 49 (1954).

29) Kamakura, K., Morikawa, A., Matsuta, M. \& Shino, T. : Jap. J. Pharmacol. 5, 93 (1956).

30) 東谷俊彦: 奈医誌 7, 217 (1956).

31) 東谷俊彦: 同誌 8,325 (1957).

32) 東谷俊彦: 同誌 8, 336 (1957).

33) Warburg, O. . Hoppe-Seyl. Z. 76, 331 (1911).

34) Corman I. : J. Ntl. Cancer Inst. 10, 1123 (1950).

35) Clark, A.J. : Arch. int. Pharmacodyn. 38, 101 (1930).

36) Bernheim, F. : 同誌 46, 169 (1933).

37) 山岡正幸 : 日薬理誌 51，164 (1955).

38) Kochmann, M. : Heffters Handb. exper. Pharmakol. Bd. 1, Springer, Berlin (1923) : 同誌 Erg. Bd. 2 (1937).

39）菅敬二郎：日薬理誌 52, 93 (1956).

40) Toman, J.E.P., Swinyard, E.A. \& Goodman, L.S. : J. Neurophysiol. 9, 231 (1946).

41) Clark, A.J. . Heffters Handb. exper. Pharmakol. Erg. Bd. 4 (1937).

42) Warburg, O. : Biochem. Z. 119, 134 (1921).

43) Lipschitz, W. \& Gottshalk, A. : Pflügers Arch. 191, 1 (1921).

44) Keilin, D. : Proc. Roy. Soc. B 98, 312 (1925).

45) Pickford, L.M. : J. Physiol. 63, 19 (1927). 